\title{
Düsseldorf tieteen ja taiteen risteyksessä
}

\section{Maunu Häyrynen}

Anne-Maria Pennonen: In Search of Scientific and Artistic Landscape: Düsseldorf Landscape Painting and Reflections of the Natural Sciences as Seen in the Artworks of Finnish, Norwegian and German Artists, Finnish National Gallery Publications 3. Kansallisgalleria, Helsinki 2020. 247 s. https://helda.helsinki.fi/hand$\underline{\text { le/10138/310026 }}$

Anne-Maria Pennonen väitteli viime kevätalvella Helsingin yliopistossa, väitöksen alana taidehistoria ja aiheena Düsseldorfin maisemamaalauksen ja luonnontieteiden välinen suhde $1800-$ luvulla. Hänen väitöskirjansa keskittyy Werner Holmbergin ja Fanny Churbergin tuotantoon, mutta käsittelee myös muiden suomalaisten, saksalaisten ja norjalaisten taiteilijoiden toimintaa Düsseldorfin taideakatemiassa ja sen yhteydessä. Kirjan päälähtökohdaksi Pennonen on valinnut valistusajattelija ja luonnontieteilijä Alexander von
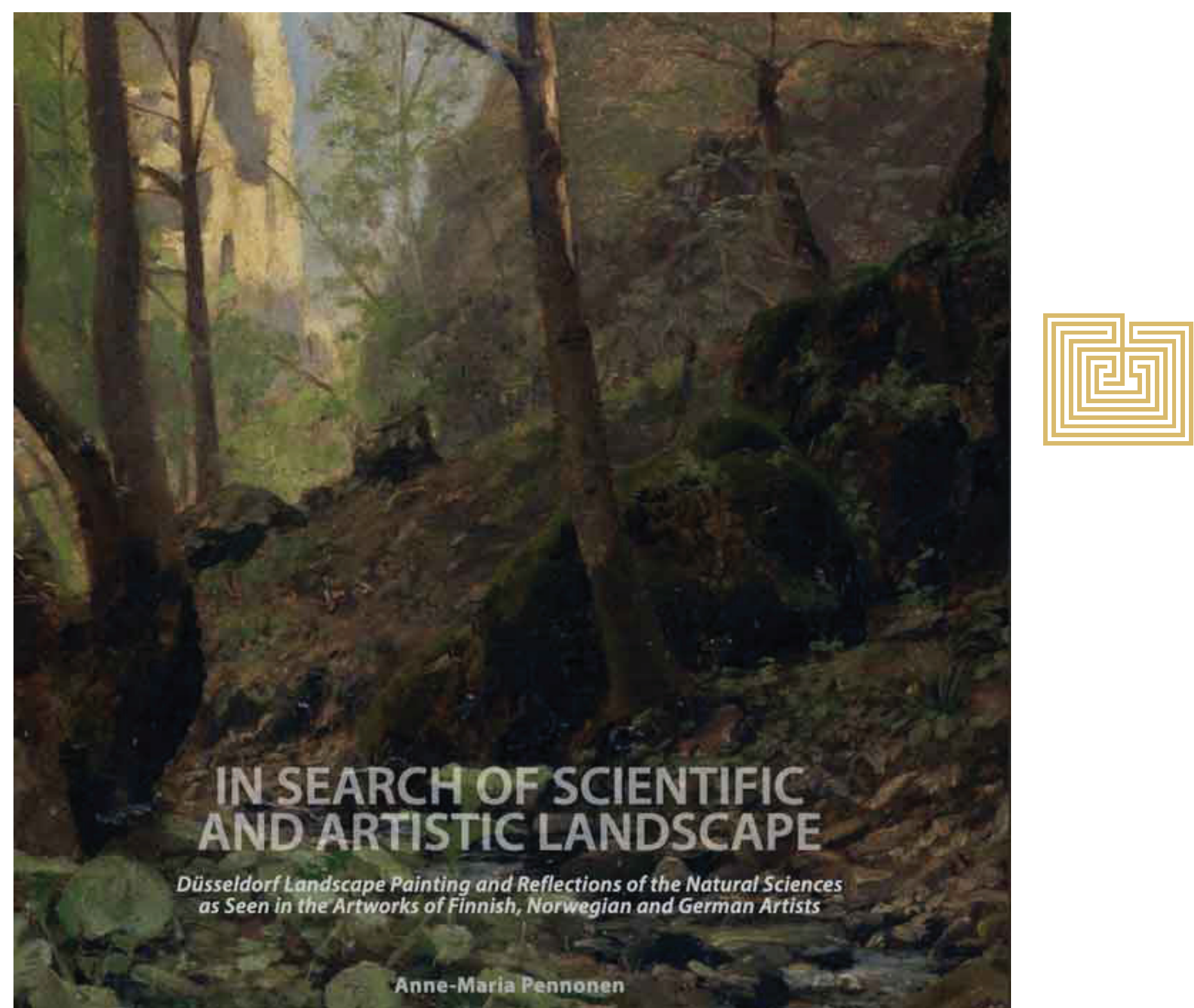
Humboldtin käsityksen maisemataiteen merkityksestä luonnon kokonaisvaltaisessa tavoittamisessa, jonka Pennonen katsoo ohjanneen düsseldorfilaistaiteilijoiden ajattelua ja taiteellista työskentelyä. Humboldtin lisäksi hän tarkastelee suomalaistaiteilijoiden kohdalla Zacharias Topeliuksen vaikutusta näiden käsityksiin suomalaisesta luonnosta ja maisemasta. Työn empiirisen aineiston muodostavat käsiteltyjen suomalaisten ja muiden taiteilijoiden teokset ja luonnokset, Düsseldorfin taideakatemian arkistolähteet, sanomalehtiaineisto sekä Holmbergin ja Churbergin osalta myös kirjeenvaihto ja päiväkirjat. Menetelminä toimivat lähiluku, lähdekritiikki ja kuva-analyysi.

\section{Lähtökohtia}

Väitöskirjan tutkimusongelmaksi asettuu luonnontieteiden kehityksen heijastuminen maisemamaalauksessa, keskiössä Düsseldorfin 1800-luvun loppupuolen maisemataide. Pennosen tavoitteena on osoittaa ajankohdan maisemamaalauksen, estetiikan, luonnonfilosofian ja luonnontieteiden luontokäsitysten samankaltaisuus. Hän kiinnittää huomiota etenkin geologian ja sääilmiöiden sekä puulajien esittämiseen teoksissa, koska nämä ilmaisevat hänen mukaansa taiteen suhdetta luonnontieteisiin. Siihen ovat liittyneet myös taiteilijoiden pyrkimys kuvausten tarkkuuteen, luonnontieteellisten kategorioiden noudattaminen ja luonnonelementtien yhdistely autenttisen kokonaisvaikutelman saavuttamiseksi kuvatusta maisemasta.
Aihepiiri on kiinnostava ja Pennosen tutkimusongelma omintakeinen. Kirja tarjoaa uuden näkökulman erityisesti düsseldorfilaiseen maisemataiteeseen ja laajemmin 1800-luvun lopun realistiseen maisemamaalaukseen. Düsseldorfin koulukuntaa taustoitetaan edeltävien vaiheiden, erityisesti Dresdenin romanttisen maisemamaalauksen kuvauksella. Luonnontieteiden ja luonnonfilosofian kehityksen osalta ajallinen painotus on 1700-luvun lopulla ja 1800 -luvun alkupuolella. 1800-luvun loppupuolen "luonnontiedettä" edustaa lähinnä Topelius, joka profiloitui ennen muuta historioitsijaksi eikä juuri tuntenut Humboldtia tai oman aikansa keskeistä maantieteilijää Carl Ritteriä. Patrioottinen Topelius tuntuu myös istuvan hieman väkinäisesti humboldtilaisen universalismin perinteen jatkajaksi.

Pennonen taustoittaa kattavasti kotimaisen maisemataiteen historian tutkimusta ja esittelee myös saksalaisia ja norjalaisia düsseldorfilaismaalareita koskevaa tutkimusta. Tekijä viittaa niin ikään paralleeleihin englantilaisen maalaustaiteen, kuten John Constablen (plein air -öljyväriluonnokset, taiteen ja luonnontieteen rinnastus) kanssa. Luonnontiedettä käsitellään etupäässä yleisen tieteenhistorian kautta, tieteen ja taiteen suhdetta varsinkin Timothy F. Mitchellin (Art and Science in German Landscape Painting, 1993) ja Topeliuksen osalta Allan Tiitan väitöskirjan (Harmaakiven maa, Zacharias Topelius ja Suomen maantiede, 1994) valossa. Pennonen ei pyri teoretisoimaan maiseman käsitettä, mutta viittaa keskenään varsin erilaisiin sitä koskeviin määritelmiin esimerkiksi ekologian (Ludwig Trepl), visuaalisen kulttuurin tutkimuksen (W. J. T. Mitchell), ympäristöpolitiikan (Yrjö Haila) ja maantieteen (Kenneth Olwig) piiristä sekä epäsuorasti itseensä Immanuel Kantiin.

\section{Humboldtin vaikutusta etsimässä}

Alexander von Humboldtin vaikutus koko 1800-luvun luonnontieteeseen on kiistaton. Monet hänen ajatuksistaan - kuten käsitys tieteen ja taiteen läheisestä suhteesta - jäivät kuitenkin luonnontieteiden kehittyessä ja erikoistuessa 1800-luvun mittaan taka-alalle. Humboldtin universalistinen kiinnostus Euroopan ulkopuolisiin ympäristöihin korvautui Ritterin ja 1800-luvun Iopulla Friedrich Ratzelin vahvemmin geopolitiikkaan ja kansallisvaltioihin ankkuroiduilla teorioilla. Valistusajattelijoiden Humboldtin ja Goethen rinnalla luonnon ja taiteen suhdetta määrittelikin etenkin 1800-luvun loppupuolella nationalismi. Sen mukaisesti kansakunnat pyrittiin esittämään luonnonkaltaisina ja luonnonympäristönsä leimaamina, ellei suorastaan tuottamina. Nationalismi loi tilausta kansallisille luonnontieteille, mikä näkyi esimerkiksi yksittäisten kansallisvaltioiden geologisissa kartoissa, kasvioissa ja muissa luonnon kansallisissa kehystyksissä. Tämä ajattelutapa näkyi vahvasti Topeliuksella ja suomalaisessa luonnontieteessä, eikä se jäänyt vaille vaikutusta myöskään düsseldorfilaisessa maalaustaiteessa.

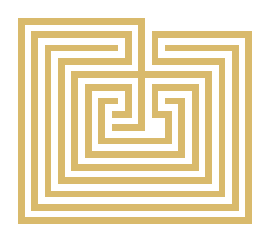


Punaisena lankana seuraa tiettyjen ennen muuta Humboldtiin assosioitujen teemojen tunnistaminen düsseldorfilaistaiteen eri piirteistä. Tällaisia ovat pyrkimys autenttisiin paikallisiin yksityiskohtiin ja niiden alueille luonteenomaisiin yhdistelmiin, luonnonilmiöiden kategorisointi luonnontieteellisen tiedon pohjalta sekä pyrkiminen näiden pohjalta kokonaisvaikutelmaan ja tunnelmaan. Pelkistäen Pennonen näkee detaljitarkat plein air -luonnokset empiiriseen tutkimukseen rinnastuvina ja jälkikäteen luodun komposition kokonaisvaikutelman tavoitteluna. Paikan päällä luonnostelun ja ateljeessa tapahtuvan lopullisen toteutuksen yhdistelmä ei ollut itsessään uutta, mutta epäilemättä luonnoksiin tukeutuva uskollisuus luonnolle sai ainakin retorista lisäpainoa 1800-luvulla.

\section{Kiinnostava näkökulma düsseldorfilaismaalareihin}

Pennosen väitöskirja onnistuu valottamaan aihettaan monipuolisesti sekä tieteen historian että maisemaestetiikan ja taideteorian näkökulmista. Maisemankuvauksen ja luonnontieteiden välillä oli 1800 -luvulla, kuten sitä ennen ja sen jälkeen, paljon vuorovaikutusta ja yhteenkietoutumista eri tasoilla, mistä työ avaa hedelmällisiä uusia tulkintoja. Kyseessä on laaja ja monenlaisia tutkimuskeskusteluja kokoava tieteidenvälinen tutkimusalue, joten on ymmärrettävää että työtä luonnehtii tietty moniäänisyys.

Väitöskirja ei pyri suoranaisesti kumoamaan aiempaa tutkimusta vaan täydentämään sitä luonnontietei- den ja maisemamaalauksen suhteen osalta. Kriittistä keskustelua aikaisemman tutkimuksen kanssa käydään siten harvakseltaan. Pennosen tutkijanääni kuuluu kuitenkin selvästi, vaikka välillä tahtookin hieman vaimentua yksityiskohtien ryteiköissä. Keskeiseksi lähtökohdaksi valittua Humboldtin vaikutusta etsitään ja löydetään väliin ehkä hieman toivorikkaastikin ottamatta täysin huomioon tämän edustaman holistisen maailmankuvan korvautumista 1800-luvun mittaan tieteenalojen eriytymisellä ja kansallisten perspektiivien nousulla.

Kaiken kaikkiaan Pennosen väitöskirja on merkittävä lisä suomalaisen 1800-luvun maisemataiteen ja maisemankuvauksen historiaan. Se valottaa sekä Düsseldorfin taideakatemian opetusmenetelmiä ja työskentelytapoja että suomalaistaiteilijoiden kansainvälisiä kontakteja. Luonnontieteen ja kuvataiteen vuoropuhelun kannalta kirja on tärkeä keskustelunavaus, jonka voi toivoa saavan jatkoa niin kotimaisessa kuin kansainvälisessäkin taidehistorian tutkimuksessa. Suurelle yleisölle työn tekevät lähestyttäväksi selkeä kieli ilman teoreettista jargonia sekä hyvin viimeistelty ulkoasu kuvituksineen.

\section{Maunu Häyrynen on taidehistorioitsija, Helsingin yliopiston taidehistorian (erity- isesti maisemantutkimuksen) dosentti ja Turun yliopiston maisemantutkimuksen professori.}

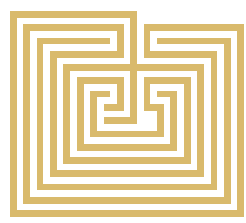

